Можайкіна Н. В., к.е.н., доцент

Маврова К. І., студентка

Харківський національний університет міського господарства імені. О. М. Бекетова м. Харків, Украӥна

DOI: https://doi.org/10.30525/978-9934-26-145-9-14

\title{
ПРОБЛЕМИ УПРАВЛІННЯ КОРПОРАТИВНИМ СЕКТОРОМ ЕКОНОМІКИ
}

Корпоративне управління в даний час є однією 3 провідних тем світової економіки. По суті воно відноситься до механізмів і системи корпоративного прийняття рішень, але воно також може включати широкий спектр інших питань, які в основному стосуються стимулів, що лежать в основі поведінки фірм. Слід зазначити, що проблема корпоративного управління 3'явилася одночасно з зародженням великих корпорацій ще у XIX-XX ст., що супроводжується процесом поділу права власності і ii управління. 3 точки зору «Принципів корпоративного управління ОЕСР», корпоративне управління має двояке значення. 3 одного боку воно охоплює відносини і стиль поведінки між різними агентами в товаристві 3 обмеженою відповідальністю. Іншими словами, корпоративне управління відноситься до засобу, яким керівники та акціонери, а також співробітники, кредитори, основні клієнти та громади взаємодіють між собою 3 метою формування стратегії корпорації [1, с. 16].

3 іншої сторони, корпоративне управління також потребує підтримки державної політики, оскільки корпоративна стратегія формується в рамках, що створюються достатньою кількістю норм. Ці норми можуть включати приватне саморегулювання, але в основному вони складаються 3 державних законів і нормативних положень, таких як закон про підприємства, законодавство про цінні папери, вимоги до допуску цінних паперів до котирування на біржі і законодавство про неплатоспроможність [2, с. 52]. Належна практика корпоративного управління не може 
розвиватися без відповідної державної політики і без адекватної законодавчої основи. Ось чому уряди в усьому світі приділяють належну увагу корпоративному управлінню.

Особливості формування корпоративного сектора в Україні мали свої слабкі міста. Перш за все, реальні зміни і модернізація на корпоративному рівні проходили повільно, в основному через існування негативних стимулів, які рухають поведінкою корпорацій. Початкові надії на те, що масова приватизація закладе фундамент для поліпшення корпоративного управління і змінить механізми стимулювання на рівні компаній так і не знайшли свого втілення. Слабкість інституціоналізації була сильно недооцінена на початковому етапі цього процесу. Очікування, що інститути і практика корпоративного управління в найкоротші терміни отримають свій розвиток на користь підприємствам i суспільству в цілому виявилися нереалістичними.

У зв'язку з відсутністю сильних інститутів, що забезпечують верховенство закону, компанії, як вітчизняні так і зарубіжні, стикаються 3 проблемами в плані забезпечення виконання контрактних зобов'язань, повернення боргів та вирішення спорів. Слабка захищеність інвестицій робить переклад активів на рахунки зарубіжних банків більш привабливим: держава чи конкурент можуть конфіскувати капітал або в будь-який час змінити правила гри для компанії. У середовищі, де існує загроза експропріації, неможливо забезпечити використання коштів за їх цільовим призначенням. Слабка корпоративна реструктуризація також $\epsilon$ результатом нездатності забезпечити довгострокові перспективи розвитку, засновані на макроекономічної стабільності. Складнощі функціонування в нестабільному оточенні звужують горизонти бізнесу i негативно відбиваються на приватному секторі економіки.

Істотне спотворення стимулів бере свій початок в рамках податкової системи. Україна досі використовує податковий кодекс, який передбачає репресивні податкові ставки для підприємств. У свою чергу, це змушує менеджерів підприємств вести подвійну бухгалтерію і обумовлює нецільове використання 
активів підприємств. Слабкий конкурентний тиск обумовлює негнучкість компаній по відношенню до розвитку ситуації на ринках. Зберігається проникаюча присутність держави в економіку шляхом прямого або опосередкованого субсидування.

У зв'язку з цим, доцільно розглянути деякі ключові проблемні аспекти корпоративного управління в Україні в контексті Принципів ОЕСР. Перш за все, захист прав акціонерів є основою будь-якої ефективної системи корпоративного управління. В цьому відношенні першим важливим правом $\epsilon$ ефективна система реєстрації права власності. Здатність брати участь в прийнятті головних рішень, що стосуються життєдіяльності компанії, головним чином через участь в загальних зборах акціонерів, також визначається як одне 3 найважливіших прав акціонерів. У цьому плані найбільш типові порушення включають відмову в наданні інформації про компанії, створення перешкод для участі у загальних зборах акціонерів, а також внесення змін до статуту компаній без прийняття відповідного рішення загальними зборами акціонерів. Крім того, відсутні інституційні інвестори, які могли б стати ініціаторами поліпшення практики корпоративного управління [3, с. 154].

Крім того, довгостроковим інтересам компаній відповідає стимулювання активної участі зацікавлених сторін у процесі корпоративного управління. Повинні ефективно дотримуватися юридичні права зацікавлених сторін (працівників, кредиторів, постачальників і споживачів).

Менеджери компаній, які часто також $\epsilon$ i акціонерами, використовують активи компаній в особистих корисливих цілях на шкоду інтересам дрібних акціонерів. В результаті, у зовнішніх інвесторів відсутня впевненість в тому, що вони зможуть реально впливати на процес прийняття рішень i, відповідно, вони не приходять на ці ринки. Працівники підприємств (не дивлячись на те, що вони одночасно є і акціонерами), отримують недостатню інформацію і грають дуже незначну роль в процесах корпоративного управління. Такі фактори як бізнес етика і корпоративне розуміння питань екології та громадських інтересів 
регіону, в якому функціонує компанія, можуть значною мірою впливати на репутацію і довгостроковий успіх компанії. Але в даний час ці питання не знаходять розуміння з боку інвесторів $\mathrm{i}$ керівників підприємств.

Належне корпоративне управління вимагає суворого режиму розкриття інформації, визнання прозорості як ключового елементу ефективної ринкової економіки. Розвиток фондових бірж України, що знаходяться в зародковому стані, може залежати від доступності фінансової та нефінансової інформації. Тому фондові біржі повинні першими впроваджувати міжнародні стандарти i практику, як в області прийняття, так і виконання правил. Наглядова рада повинна бути основним механізмом для ефективного контролю правління і стратегічного керівництва корпорації.

Хоча ефективне корпоративне управління не може існувати без належного державного управління, останнє не зможе вкоренитися якщо приватний сектор економіки і його головні учасники, компанії не стануть прозорими і законослухняними. Розуміння цієї взаємозалежності має бути ключовим аспектом будь-яких реформ.

В цілому можна виділити кілька загальносвітових тенденцій, які характерні для подальшого вдосконалення корпоративного права: посилення вимог «прозорості» (розкриття інформаціі) АТ; паралельний процес посилення правомочностей органів управління АТ та контролю за органами управління з боку акціонерів; розширення судового контролю за діяльністю АТ; розвиток законодавства щодо захисту прав дрібних акціонерів по всьому спектру проблем (переважне право покупки акцій нових випусків, кваліфіковане (або вище) більшість, правила злиттів і поглинань, кумулятивне голосування та ін.); розвиток законодавства щодо захисту прав кредиторів АТ; посилення регламенту випуску акцій, зміни статутного капіталу, введення вимог неприпустимість збільшення прибутку за рахунок основного капіталу; зближення правового статусу акції і облігації; особливу увагу до питань реорганізації АТ, перетворення АТ в інші види 
товариств і навпаки; посилення регулювання взаємовідносин між різними юридично незалежними, але економічно взаємопов'язаними АТ [4, с. 98].

\section{Література:}

1. Баюра Д.О. Корпоративна реформа в Україні: системний підхід до формування ринкової соціально-орієнтованої моделі корпоративного управління. Теоретичні та прикладні питання економіки. 2016. Вип. 1. С. 15-22.

2. Сірко А.В. Корпоративні відносини в перехідній економіці: проблеми теорії і практики. Київ : Імекс, 2004. 414 с.

3. Птащенко Л.А. Сбалансированность экономических интересов: инновационные направления государственного и корпоративного стратегического управления: монография. Москва : Центр учебной литературы, 2009. 296 с.

4. Юрчишина А.В. Акціонерні товариства: тенденції, проблеми функціонування та дивідендна політика. Східна Європа: економіка, бізнес та управління. 2017. Вип. 3 (08). С. 95-101. 